\title{
KEDUDUKAN PERATURAN MENTERI TERHADAP PEMBENTUKAN PERATURAN DAERAH
}

\section{RISKI}

riski.311091@gmail.com

Biro Hukum Pemerintah Kota Tarakan

\begin{abstract}
Regional Regulation which in principle are formed in the context of carrying out government affairs which are the authority of the regions, in fact are considered to be contrary to ministerial regulation. This is because the position and content of the ministerial regulation has not been regulated in the Law on the formation of regulation, while the level of dynamics of change is very high and fast compared to local regulations whose formation is influenced by political interests in the region and requires a long time. The problems discussed in this study were the legis ratio of the position of ministerial regulation according to Law Number 12 of 2011 concerning the formation of regulations and the juridical implications of the position of ministerial regulation on the formation of regional regulations. This study aimed to determine the legis ratio of ministerial regulation according to Law Number 12 of 2011 concerning the formation of legislation and the juridical implications of the position of ministerial regulation on the formation of regional regulations. This research was expected to contribute thoughts both theoretically and practically to the dynamics of legal development in Indonesia. The research used normative juridical method that consisted of primary, secondary and non legal materials. From the results of the study it was concluded that, First, the position of ministerial regulation is a legislation that was formed based on the order of higher legislation (delegated legislation), while ministerial regulation which was formed based on authority is a policy regulation (Beleidsregel). Second, regional regulation must refer to and base their formation on ministerial regulation, if the ministerial regulations is formed based on the authority of attribution and/or delegation of the formation of legislation and its position contained in the hierarchy of statutory regulations and not formed based on the authority to administer government affairs (Bestuur).
\end{abstract}

Keywords: Status of Regulations, Ministerial Regulation, Regional Regulation. 


\section{PENDAHULUAN}

Undang-Undang Nomor 23 Tahun 2014 tentang Pemerintahan Daerah dalam konsideran huruf $\mathrm{b}$ menyatakan bahwa penyelenggaraan pemerintahan daerah diarahkan untuk mempercepat terwujudnya kesejahteraan masyarakat melalui peningkatan pelayanan, pemberdayaan, dan peran serta masyarakat, serta peningkatan daya saing daerah dengan memperhatikan prinsip demokrasi, pemerataan, keadilan, dan kekhasan suatu daerah dalam sistem Negara Kesatuan Republik Indonesia. ${ }^{16}$ Selanjutnya pada bagian umum alinea kelima penjelasanya dijelaskan bahwa daerah sebagai satu kesatuan masyarakat hukum yang mempunyai otonomi berwenang mengatur dan mengurus daerahnya sesuai aspirasi dan kepentingan masyarakatnya sepanjang tidak bertentangan dengan tatanan hukum nasional dan kepentingan umum. Dalam rangka memberikan ruang yang lebih luas kepada daerah untuk mengatur dan mengurus kehidupan warganya maka pemerintah pusat dalam membentuk kebijakan harus memperhatikan kearifan lokal dan sebaliknya daerah ketika membentuk kebijakan daerah baik dalam bentuk Perda maupun kebijakan lainnya hendaknya juga memperhatikan kepentingan nasional. Dengan demikian akan tercipta keseimbangan antara kepentingan nasional yang sinergis dan tetap memperhatikan kondisi, kekhasan, dan kearifan lokal dalam penyelenggaraan pemerintahan secara keseluruhan. ${ }^{17}$

Pembentukan Perda tidak sedikit yang mendasarkan pembentukannya pada Peraturan Menteri, baik dari aspek formiil (Legal Drafting) maupun pada aspek materiil (materi muatan). Peraturan Menteri pada praktiknya, seringkali mengacaukan Perda, baik yang dalam proses pembentukan yang masih berbentuk rancangan perda maupun perda yang sudah ditetapkan dan berkekuatan hukum mengikat. Sebagai contoh dan fakta yang terjadi dilapangan,

\footnotetext{
${ }^{16}$ Lihat Konsideran huruf b Undang-Undang Nomor 23 Tahun 2014 tentang Pemerintahan Daerah

${ }^{17}$ Lihat Penjelasan umum alinea kelima Undang-Undang Nomor 23 Tahun 2014 tentang Pemerintahan Daerah.
}

119 | Pasca Sarjana Magister Hukum Universitas Borneo Tarakan 
penyusunan rancangan Perda Kota Tarakan tentang Minuman Beralkohol yang sebelumnya telah masuk kedalam Program Pembentukan Peraturan Daerah (Propemperda) dan telah dilengkapi dengan naskah akademik dan draf rancangan peraturan daerahnya, pada perjalanannya harus diubah dan disesuaikan mengingat Peraturan Menteri Perdagangan yang menjadi landasan yuridis penyusunan naskah akademiknya dicabut dan diganti dengan yang baru, hal tersebut tentu membuat pembentuk perda harus mengulang pekerjaannya kembali ketitik awal. Contoh lain adalah terbitnya Peraturan Menteri Kelautan dan Perikanan yang mengakibatkan Perda Kota Tarakan tentang Izin Usaha Perikanan harus diubah dan disesuaikan.

Tingkat dinamika perubahan Peraturan Menteri sebagai peraturan sektoral di tingkat pusat sangat tinggi, belum lagi ketidakjelasan materi muatan dari Peraturan Menteri dimana pengaturannya juga tidak dapat kita temukan di dalam Undang-Undang Nomor 12 Tahun 2011 tentang Pembentukan Peraturan Perundang-undangan, di sisi lain justru sebaliknya proses pembentukan Perda yang syarat akan tarik ulur kepentingan politik dan dinamika pembahasan para pembentuknya di daerah cukup menguras fikiran dan memerlukan waktu yang lama, belum lagi kompetensi para pembentuk Perda pada tiap-tiap daerah juga berbeda-beda, sehingga pertanyaan mendasar yang penulis ajukan dalam penelitian ini adalah apakah Peraturan Menteri yang ada sekarang ini masih relevan untuk dijadikan dasar dalam pembentukan Perda, hal inilah yang menjadi pokok persoalan dalam pembentukan Perda baik Perda pada tingkat Provinsi maupun Kabupaten/Kota. Secara teoritis, keberadaan hierarki peraturan perundang-undangan dalam kehidupan ketatanegaraan Indonesia merupakan sebuah sistem untuk menjaga adanya konsistensi dan ketaatan asas dalam hukum positif di Indonesia. ${ }^{18}$ Terdapat larangan pertentangan antara suatu norma hukum dengan norma hukum yang lain juga semata demi memberi jaminan kepastian hukum kepada masyarakat.

\footnotetext{
${ }^{18}$ Dian Agung Wicaksana, Implikasi dan Re-Eksistensi Tap MPR dalam Hierarki Peraturan Perundangundangan terhadap Jaminan atas Kepastian Hukum yang Adil di Indonesia, Jurnal Konstitusi, Vol. 10 No. 1, Maret 2013, h. 151-152
}

\section{0 | Pasca Sarjana Magister Hukum Universitas Borneo Tarakan}


Berangkat dari beberapa persoalan yuridis yang telah penulis uraiakan di atas dan fakta-fakta permasalahan yang terjadi di lapangan, penulis menganggap perlu untuk melakukan penelitian hukum dengan judul Kedudukan Peraturan Menteri Terhadap Pembentukan Peraturan Daerah.

\section{RUMUSAN MASALAH}

Adapun yang menjadi rumusan masalah pada penelitian ini adalah:

1. Ratio legis kedudukan Peraturan Menteri menurut Undang-Undang Nomor 12 Tahun 2011 tentang Pembentukan Peraturan Perundang-undangan.

2. Implikasi yuridis kedudukan Peraturan Menteri terhadap pembentukan Peraturan Daerah.

\section{METODE PENELITIAN}

Metode penelitian yang digunakan dalam penelitian ini adalah tipe penelitian yuridis normatif dengan 2 (dua) pendekatan masalah, yaitu Pendekatan Perundang-Undangan (Statute Approach) dan Pendekatan Konseptual (Conceptual Approach).

\section{PEMBAHASAN}

Ratio Legis Kedudukan Peraturan Menteri Menurut Undang-Undang Nomor 12 Tahun 2011 Tentang Pembentukan Peraturan PerundangUndangan.

1. Kedudukan Peraturan Menteri sebagai peraturan perundangundangan.

Peraturan Menteri dalam Undang-Undang Nomor 12 Tahun 2011 tentang Pembentukan Peraturan Perundang-undangan tidak diatur dalam ketentuan Pasal 7 ayat (1). Namun demikian, keberadaan Peraturan Menteri dapat kita temukan dalam ketentuan Pasal 8 ayat (1) Undang-Undang Nomor 12 Tahun 2011 tentang Pembentukan Peraturan Perundang-undangan, yang mengatur bahwa:

"Jenis Peraturan Perundang-undangan selain sebagaimana dimaksud

121 | Pasca Sarjana Magister Hukum Universitas Borneo Tarakan 
dalam Pasal 7 ayat (1) mencakup peraturan yang ditetapkan oleh Majelis Permusyawaratan Rakyat, Dewan Perwakilan Rakyat, Dewan Perwakilan Daerah, Mahkamah Agung, Mahkamah Konstitusi, Badan Pemeriksa Keuangan, Komisi Yudisial, Bank Indonesia, Menteri, badan, lembaga, atau komisi yang setingkat yang dibentuk dengan Undang-Undang atau Pemerintah atas perintah Undang-Undang, Dewan Perwakilan Rakyat Daerah Provinsi, Gubernur, Dewan Perwakilan Rakyat Daerah Kabupaten/Kota, Bupati/Walikota, Kepala Desa atau yang setingkat."19

Ketentuan tersebut walaupun tidak menyebut secara tegas jenis peraturan perundang-undangan berupa "Peraturan Menteri", namun frase “...peraturan yang ditetapkan oleh... menteri...” di atas, mencerminkan keberadaan Peraturan Menteri sebagai salah satu jenis peraturan perundangundangan. Selain itu Undang-Undang tersebut juga mengatur tentang kekuatan mengikat dari Peraturan Menteri, hal ini dapat kita lihat dalam ketentuan Pasal 8 ayat (2) Undang-Undang Nomor 12 Tahun 2011 yang mengatur bahwa:

"Peraturan Perundang-undangan sebagaimana dimaksud pada ayat (1) diakui keberadaannya dan mempunyai kekuatan hukum mengikat sepanjang diperintahkan oleh Peraturan Perundang-undangan yang lebih tinggi atau dibentuk berdasarkan kewenangan." 20

Dari ketentuan di atas, terdapat dua syarat agar peraturan sebagaimana dimaksud dalam Pasal 8 ayat (1) Undang-Undang Nomor 12 Tahun 2011 tentang Pembentukan Peraturan Perundang-undangan termasuk di dalamnya adalah Peraturan Menteri, memiliki kekuatan mengikat sebagai peraturan perundang-undangan, yaitu:

a. diperintahkan oleh peraturan perundang-undangan yang lebih tinggi; atau

b. dibentuk berdasarkan kewenangan.

\footnotetext{
${ }^{19}$ Lihat Pasal 8 ayat (1) Undang-Undang Nomor 12 Tahun 2011 tentang Pembentukan Peraturan Perundang-undangan

${ }^{20}$ Lihat Pasal 8 ayat (2) Undang-Undang Nomor 12 Tahun 2011 tentang Pembentukan Peraturan Perundang-undangan
}

122 | Pasca Sarjana Magister Hukum Universitas Borneo Tarakan 


\section{Kalimat "diperintahkan oleh peraturan perundang-undangan yang}

lebih tinggi" mengandung makna sebagai kewenangan delegasi, ini berarti bahwa Peraturan Menteri hanya dapat dibentuk jika terdapat ketentuan didalam peraturan perundang-undangan yang lebih tinggi yang memerintahkan untuk membentuk Peraturan Menteri. Sedangkan yang dimaksud dengan "dibentuk berdasarkan kewenangan" harus dimaknai sebagai kewenangan atribusi membentuk peraturan dan bukan kewenangan penyelenggaraan urusan pemerintahan (bestuur), hal ini berarti bahwa dalam membentuk peraturan, Menteri harus memiliki kewenangan atribusi yang diberikan oleh Undang-Undang.

\section{- Fungsi Hierarki Peraturan Perundang-undangan.}

Ajaran Hans Kelsen mengenai Sfufenbau des Recht atau The hierarchy of law yang pada intinya menyatakan bahwa kaidah hukum merupakan suatu susunan berjenjang dan setiap kaidah hukum yang lebih rendah bersumber dari kaidah yang lebih tinggi. Untuk lebih memahami teori Stufenbau des Recht, harus dihubungkan dengan ajaran Kelsen yang lain yaitu Reine Rechtslehre atau The pure theory of law (teori mumi tentang hukum) dan bahwa hukum itu tidak lain "command of the sovereign" kehendak yang berkuasa. ${ }^{21}$ Hans Kelsen mengatakan bahwa hukum termasuk dalam sistem norma yang dinamik (nomo dynamics) karena hukum itu selalu dibentuk dan dihapus oleh lembaga-lembaga atau otoritas-otoritas yang berwenang membentuknya, sehingga dalam hal ini tidak kita ihat dari segi isi norma tersebut, tetapi dari segi berlakunya atau pembentukannya. ${ }^{22}$ Hukum itu adalah sah (valid) apabila dibuat oleh lembaga atau otoritas yang berwenang membentuknya dan berdasarkan norma yang lebih tinggi sehingga dalam hal ini norma yang lebih rendah (inferior) dapat dibentuk oleh norma yang lebih tinggi (superior), dan hukum itu berjenjang-jenjang dan berlapis-lapis

\footnotetext{
${ }^{21}$ Bagir Manan, Teori dan Politk Konstitusi Cetakan Kedua, FH UII Press, Yogyakarta, 2004, h. 201-202.

${ }^{22}$ Ibid, h. 203.
}

123 | Pasca Sarjana Magister Hukum Universitas Borneo Tarakan 
membentuk hierarki, di mana suatu norma yang lebih rendah berlaku, bersumber, dan berdasar pada norma yang lebih tinggi, norma yang lebih tinggi berlaku, bersumber dan berdasar pada norma yang lebih tinggi lagi, demikian seterusnya sampai pada suatu norma yang tidak dapat ditelusuri lebih lanjut dan bersifat hipotetis dan fiktif, yaitu norma dasar (grundnorm). ${ }^{23}$ Ajaran tentang tata urutan peraturan perundang-undangan demikian mengandung beberapa prinsip, diantaranya: ${ }^{24}$

a. Peraturan perundang-undangan yang lebih tinggi kedudukannya dapat dijadikan landasan atau dasar hukum bagi peraturan perundang- undangan yang lebih rendah atau berada di bawahnya.

b. Peraturan perundang-undangan tingkat lebih rendah harus bersumber atau memiliki dasar hukum darl suatu peraturan perundang-undangan tingkat lebih tinggi.

c. Isi atau muatan peraturan perundang-undangan yang lebih rendah tidak boleh menyimpangi atau bertentangan dengan peraturan perundang- undangan yang lebih tinggi tingkatannya.

d. Suatu peraturan perundang-undangan hanya dapat dicabut atau diganti atau diubah dengan peraturan perundang-undangan yang lebih tinggi atau paling tidak dengan yang sederajat.

e. Peraturan-peraturan perundang-undangan yang sejenis apabila mengatur materi yang sama, maka peraturan yang terbaru harus diberlakukan, walaupun tidak dengan secara tegas dinyatakan bahwa peraturan yang lama itu dicabut. Selain itu. peraturan yang mengatur materi yang lebih khusus harus diutamakan dari peraturan perundang- undangan yang lebih umum.

Sejalan dengan konsep pembentukan peraturan perundang-undangan maka keberadaan penjenjangan/hirarki akan menjadi sangat penting untuk diperhatikan, karena penjenjangan atau hirarki tersebut akan sangat mempengaruhi bagaimana kedudukan dari peraturan-peraturan itu. Ketidak tertiban hirarki atau ketidak jelasan penempatan suatu peraturan perundang-undangan dalam hirarki akan mengakibatkan kesulitan dalam

\footnotetext{
${ }^{23}$ Ni'matul Huda, Kedudukan Perda dalam hierarki Peraturan Perundang-undangan, Jurnal Hukum No. 1 Vol 13 Januari 2016, h. 30

${ }^{24} 10$ Bagir Manan, Teori dan..., Op.Cit., h. 133. Lihat juga dalam Rosjldi Ranggawidjaja, Pedoman Teknik Perancangan Peraturan Perundang-undangan, Cita Bhakti Akademika, Bandung, 1996, h. 19
}

124 | Pasca Sarjana Magister Hukum Universitas Borneo Tarakan 
mengetahui penempatan kedudukan dan pengujian peraturan perundangundangan. ${ }^{25}$

Dari beberapa uraian di atas, menurut penulis, fungsi dari hierarki peraturan perundang-undangan adalah sebagai suatu sistem yang dibentuk untuk menjamin kedudukan dan kekuatan dari keberadaan suatu peraturan perundang-undangan, dengan adanya hierarki kita dapat melihat pada posisi mana suatu peraturan itu berada dan dari mana sumber pembentukannya termasuk juga wewenang apa yang ada dibawahnya.

\section{Urgensi Pengaturan Materi Muatan Peraturan Menteri}

Pada dasarnya Menteri sebagai pembantu Presiden, dalam sistem pemerintahan presidensiil, mempunyai kewenangan untuk mengatur di bidang tugas pemerintahan mereka masing-masing. Menteri pada dasarnya mempunyai pengaruh besar terhadap Presiden dalam menentukan politik negara yang berhubungan dengan bidang tugasnya. Walaupun dalam menetapkan politik pemerintahan dan koordinasi di dalam pemerintahan negara, para Menteri harus bekerjasama satu sama lain dan seerat-eratnya di bawah kepemimpinan Presiden. ${ }^{26}$ Mengingat pengaruh besarnya tersebut, kebutuhan Menteri untuk mengatur adalah penting, agar politik pemerintahan yang telah ditetapkan dapat terealisasikan.

Secara teoritis Peraturan Menteri hasil dari kewenangan delegasian merupakan Peraturan Perundang-undangan, dan kebutuhan di daerah yang membutuhkan petunjuk lebih lanjut, maka sebaiknya Peraturan Menteri (yang merupakan hasil dari kewenangan delegasian) dimasukan dalam hierarki Peraturan Perundang-undangan. ${ }^{27}$ Hal tersebut sesuai dengan

\footnotetext{
${ }^{25}$ Yahya Ahmad Zein, Problematika Hirarkhi Peraturan Peundang-undangan Indonesia (Studi Pasal 8 ayat (1) UU 12 tahun 2011 tentang Pembentukan Peraturan peraturan perundangundangan, Konfrensi Nasional Hukum Tata Negara ke-4, Jember, 10-13 November 2017, h. 1

${ }^{26}$ Maria Farida, Ilmu Perundang-undangan, Jenis Fungsi dan Materi Muatan, Kanisius, Yogyakarta, 2007, h. 156.

${ }^{27}$ Naskah Akademik Rancangan Undang-Undang tentang Perubahan atas Undang- Undang Nomor 10 Tahun 2004 tentang Pembentukan Peraturan Perundang-undangan.
}

125 | Pasca Sarjana Magister Hukum Universitas Borneo Tarakan 
arahan dari Naskah Akademik Rancangan Undang-Undang tentang Perubahan atas Undang-Undang Nomor 10 Tahun 2004 tentang Pembentukan Peraturan Perundang-undangan. Naskah Akademik UndangUndang tersebut juga menjelaskan bahwa perlu adanya kejelasan mengenai substansi dari Peraturan Menteri yang bersifat teknis. Sedangkan makna dari 'bersifat teknis' ini sebaiknya didefinisikan dalam aturannya. ${ }^{28}$

Urgensi pengaturan materi muatan peraturan menteri sebenarnya telah dimuat dalam Naskah Akademik Rancangan Undang-Undang tentang Perubahan Atas Undang-Undang Nomor 10 Tahun 2004 tentang Pembentukan Peraturan Perundang-undangan sebagaimana telah diuraikan di atas, namun faktanya Naskah Akademik tersebut tidak digunakan, DPR yang merupakan inisiator rancangan undang-undang dimaksud justru menyusun Naskah Akademik baru yang didalamnya tidak dapat kita temukan pembahasan secara terperinci yang berkaitan dengan Peraturan Menteri.

4. Arah Perubahan Berikutnya Undang - Undang tentang Pembentukan Peraturan Perundang-undangan

Undang-Undang Nomor 15 Tahun 2019 tentang Perubahan atas Undang-Undang Nomor 12 Tahun 2011 tentang Pembentukan Peraturan Perundang-undangan pada kenyataannya belum mengakomodir perubahan terhadap ketentuan Pasal 7 dan Pasal 8 Undang-Undang dimaksud oleh karenanya dalam rangka penataan regulasi sebaiknya dilakukan revisi kembali terhadap Undang-Undang Nomor 12 Tahun 2011 tentang Pembentukan Peraturan Perudang-undangan khususnya pada Pasal 7 ayat (1) yang mengatur terkait hierarki peraturan perundang-undangan dengan memasukkan Peraturan Menteri yang terkategori sebagai peraturan perundang-undangan delegasian (delegated legislation) kedalam hierarki peraturan perundang-undangan di bawah Peraturan Presiden, mengingat

${ }^{28}$ Ibid

126 | Pasca Sarjana Magister Hukum Universitas Borneo Tarakan 
Menteri adalah pembantu Presiden, selanjutnya Peraturan Menteri yang terkategori sebagai Peraturan Kebijakan (beleidsregel), harus tetap diakui keberadaannya dalam Undang-Undang tentang Pembentukan Peraturan Perundang-undangan, mengingat peraturan tersebut secara faktual masih dibutuhkan sepanjang memuat ketentuan teknis dalam rangka pengaturan hal-hal yang berkaitan dengan Norma, Standar, Kriteria, dan Prosedur (NSPK) urusan Pemeirntahan tertentu. Selain kebutuhan penempatan Peraturan Menteri kedalam hierarki peraturan perundang-undangan, kebutuhan terkait pengaturan materi muatan Peraturan Menteri juga sangat mendesak untuk dilakukan pada Perubahan Undang-Undang tentang Pembentukan Peraturan Perudang-undangan, mengingat selama ini tidak terdapat pengaturan terkait hal apa saja yang dapat dimuat dalam suatu Peraturan Menteri. Hal tersebut penting untuk dilakukan untuk memastikan apakah Peraturan Menteri tersebut terkategori sebagai Peraturan Perundang-undangan atau sebagai Peraturan Kebijakan. Selain itu, pengaturan materi muatan Peraturan Menteri diharapkan juga mampu untuk mengurangi obesitas regulasi dengan tujuan untuk membatasi hal-hal apa saja yang dapat dituangkan menjadi suatu produk berbentuk peraturan.

Selain kebutuhan terhadap perubahan hierarki peraturan perundangundangan dan materi muatan dari Peraturan Menteri, salah satu materi pokok yang harus dimuat dalam Perubahan Undang-Undang tentang Pembentukan Peraturan Perundang-undangan yang akan datang adalah mengakomodir konsep Omnibus Law. Secara sederhana Omnibus Law dapat diartikan sebagai penyederhanaan beberapa undang-undang dengan urgensi yang berbeda kedalam satu undang-undang dengan urgensi yang sama. Secara teoritis tanpa melakukan perubahan terhadap Undang-Undang tentang Pembentukan Peraturan Perundang-undangan, konsep Omnibus Law dapat dilaksanakan mengingat bentuknya juga dalam bentuk UndangUndang. Namun menurut hemat Penulis, secara praktis hal tersebut perlu 
dilakukan untuk memberi legitimasi terhadap konsep Omnibus Law sebagai brand reformasi di bidang peraturan perundang-undangan yang digagas oleh Pemerintah saat ini, selain itu kriteria materi muatan dan petunjuk yang bersifat teknis dalam pelaksanaan Omnibus Law juga perlu diatur di dalam Undang-Undang tentang Pembentukan Peraturan Perundang-undangan untuk memastikan pelaksanaan Omnibus Law tidak menimbulkan persoalan hukum baru dan sesuai dengan ketentuan peraturan perundang-undangan yang ada.

Penulis berpendapat bahwa perlu melakukan perubahan secara totalitas terhadap Undang-Undang tentang Pembentukan Peraturan Perundang-undangan dengan cara menerbitkan Undang-Undang tentang Pembentukan Peraturan Perundang-undangan yang baru sebagai pengganti Undang-Undang yang ada, yang memuat tentang:

a. Jenis-jenis peraturan yang dapat dibentuk;

b. Institusi yang memiliki wewenang membentuk;

c. Syarat dan tata cara pembentukannya;

d. Batasan materi muatan yang diatur;

e. Posisi kedudukan dan kekuatan hukum dari suatu peraturan;

f. Mekanisme dan institusi yang berwenang melakukan pengujian; dan

g. Mengatur mengenai ketentuan sanksi bagi pembentuk peraturan perundang-undangan yang tidak mematuhi ketentuan terkait pembentukan peraturan perundang-undangan untuk menjamin efektifitas dari pelaksanaan Undang-Undang tentang Pembentukan Peraturan Perundang-undangan dimaksud, hal ini penting mengingat dampak yang ditimbulkan dari pemberlakukan suatu peraturan dirasakan langsung oleh masyarakat luas serta untuk mencegah terjadinya abuse of power oleh pembentuk peraturan.

Secara garis besar materi muatan dalam Undang-Undang Nomor 15 Tahun 2019 tentang Perubahan atas Undang-Undang Nomor 12 Tahun 2011 
tentang Pembentukan Peraturan Perundang-undangan, memuat 3 (tiga) pokok perubahan yaitu:

a. Carry-over, bahwa Rancangan Undang-Undang yang telah mencapai pembahasan Daftar Invetarisasi Masalah (DIM) dan belum selesai, disampaikan kepada DPR periode berikutnya serta dapat dimasukkan kembali dalam Prolegnas jangka menengah dan/atau Prolegnas prioritas tahunan. (Pasal $71 \mathrm{~A}$ )

b. Pemantauan dan Peninjauan terhadap Undang-Undang, kegiatan ini

bertujuan untuk mengetahui ketercapaian, dampak, dan kemanfaatan atas pelaksanaan suatu Undang-Undang (Pasal 95A dan Pasal 95B); dan

c. Pembentukan peraturan perundang-undangan di lingkungan Pemerintah dikoordinasikan oleh Menteri dan Kepala Lembaga yang menyelenggarakan urusan pemerintahan di bidang Pembentukan Peraturan Perundang-undangan. (Pasal 21 ayat (4), 23 ayat 2, 26 ayat 1, 47 ayat 3,49 ayat 3,54 ayat 2,55 ayat 22,58 ayat $2,85,91$ ayat 1 .)

\section{Implikasi Yuridis Kedudukan Peraturan Menteri Terhadap Pembentukan} Peraturan Daerah.

\section{Hubungan Pemerintah Pusat dengan Pemerintah Daerah dalam}

\section{Penyelenggaraan Otonomi Daerah.}

Uraian tentang Hubungan antara Pemerintah Pusat dan Pemerintah Daerah dapat kita temukan di dalam Penjelasan Undang-Undang Nomor 23 Tahun 2014 tentang Pemerintahan Daerah, di dalam penjelasan tersebut diuraikan bahwa Pemberian otonomi yang seluas-seluasnya kepada Daerah dilaksanakan berdasarkan prinsip negara kesatuan. Dalam negara kesatuan kedaulatan hanya ada pada pemerintahan negara atau pemerintahan nasional dan tidak ada kedaulatan pada Daerah. Oleh karena itu, seluas apa pun otonomi yang diberikan kepada Daerah, tanggung jawab akhir penyelenggaraan Pemerintahan Daerah akan tetap ada ditangan Pemerintah Pusat. Untuk itu Pemerintahan Daerah pada negara kesatuan merupakan 
satu kesatuan dengan Pemerintahan Nasional. Sejalan dengan itu, kebijakan yang dibuat dan dilaksanakan oleh Daerah merupakan bagian integral dari kebijakan nasional. Pembedanya adalah terletak pada bagaimana memanfaatkan kearifan, potensi, inovasi, daya saing, dan kreativitas Daerah untuk mencapai tujuan nasional tersebut di tingkat lokal yang pada gilirannya akan mendukung pencapaian tujuan nasional secara keseluruhan. Daerah sebagai satu kesatuan masyarakat hukum yang mempunyai otonomi berwenang mengatur dan mengurus Daerahnya sesuai aspirasi dan kepentingan masyarakatnya sepanjang tidak bertentangan dengan tatanan hukum nasional dan kepentingan umum. Dalam rangka memberikan ruang yang lebih luas kepada Daerah untuk mengatur dan mengurus kehidupan warganya maka Pemerintah Pusat dalam membentuk kebijakan harus memperhatikan kearifan lokal dan sebaliknya Daerah ketika membentuk kebijakan Daerah baik dalam bentuk Perda maupun kebijakan lainnya hendaknya juga memperhatikan kepentingan nasional. Dengan demikian akan tercipta keseimbangan antara kepentingan nasional yang sinergis dan tetap memperhatikan kondisi, kekhasan, dan kearifan lokal dalam penyelenggaraan pemerintahan secara keseluruhan.

\section{Kedudukan Peraturan Daerah dalam Hierarki Peraturan Perundang-} undangan.

Kedudukan Perda dalam hierarki peraturan perundang-undangan dapat dilihat dalam ketentuan Pasal 7 (1) Undang-Undang Nomor 12 Tahun 2011 tentang Pembentukan Peraturan Peraturan Perundang-undangan. Pasal tersebut, menetapkan jenis dan hierarki peraturan perundangundangan dengan urutan sebagai berikut: ${ }^{29}$
a. Undang-undang Dasar Negara Republik Indonesia Tahun 1945;
b. Ketetapan Majelis Permusyawaratan Rakyat
c. Undang-Undang/Peraturan Pemerintah Pengganti Undang-Undang;
d. Peraturan Pemerintah;

\footnotetext{
${ }^{29}$ Lihat Pasal 7 ayat (1) Undang-Undang Nomor 12 Tahun 2011 tentang Pembentukan Peraturan Perundang-undangan.
}

130 | Pasca Sarjana Magister Hukum Universitas Borneo Tarakan 
e. Peraturan Presiden;

f. Perda Provinsi;

g. Perda Kabupaten/Kota.

Dilihat dari susunan di atas, maka Perda baik Perda Provinsi maupun Perda Kabupaten/Kota merupakan peraturan perundang-undangan terendah dalam sistem hierarki peraturan perundang-undangan. Hal penting dari perumusan tata urutan peraturan perundang-undangan tersebut adalah bahwa peraturan perundang-undangan Republik Indonesia merupakan suatu sistem yang tunduk pada mekanismenya sendiri. Hal ini juga sejalan dengan amanat dari Undang-Undang Nomor 23 Tahun 2014 tentang Pemerintahan Daerah, pada Penjelasan Umum Undang-Undang tentang Pemerintahan Daerah dijelaskan bahwa dalam melaksanakan Urusan Pemerintahan yang menjadi kewenangan Daerah, kepala daerah dan DPRD selaku penyelenggara Pemerintahan Daerah membuat Perda sebagai dasar hukum bagi Daerah dalam menyelenggarakan Otonomi Daerah sesuai dengan kondisi dan aspirasi masyarakat serta kekhasan dari Daerah tersebut. Perda yang dibuat oleh Daerah hanya berlaku dalam batas-batas yurisdiksi Daerah yang bersangkutan. Walaupun demikian Perda yang ditetapkan oleh Daerah tidak boleh bertentangan dengan ketentuan peraturan perundang-undangan yang lebih tinggi tingkatannya sesuai dengan hierarki peraturan perundangundangan. Disamping itu Perda sebagai bagian dari sistem peraturan perundang-undangan tidak boleh bertentangan dengan kepentingan umum sebagaimana diatur dalam kaidah penyusunan Perda. ${ }^{30}$

\section{Urgensi Pembentukan Peraturan Daerah dan Hubungannya dengan Peraturan Menteri.}

Pasal 17 ayat (1) mengatur bahwa "Daerah berhak menetapkan kebijakan Daerah untuk menyelenggarakan Urusan Pemerintahan yang menjadi kewenangan Daerah." Ketentuan ini secara langsung menegaskan

\footnotetext{
${ }^{30}$ Lihat Penjelasan Umum Undang-Undang Nomor 23 Tahun 2014 tentang Pemerintahan
}

\section{1 | Pasca Sarjana Magister Hukum Universitas Borneo Tarakan}


bahwa pembentukan kebijakan daerah khususnya dalam bentuk Perda merupakan Hak Daerah yang didelegasikan langsung oleh Undang-Undang. Namun hak tersebut tidak serta merta dapat dilaksanakan secara bebas oleh pemerintah daerah, Pasal 17 ayat (2) selanjutnya mengatur bahwa "Daerah dalam menetapkan kebijakan Daerah sebagaimana dimaksud pada ayat (1), wajib berpedoman pada norma, standar, prosedur, dan kriteria yang telah ditetapkan oleh Pemerintah Pusat." Pengaturan yang demikian bukan dalam rangka membatasi daerah dalam melaksanakan kebijakan daerah, tetapi sesuai dengan penjelasan umum sebagaimana yang telah diuraikan di atas, bahwa kewajiban pemerintah daerah untuk berpedoman pada norma, standar, prosedur dan kriteria dimaksud adalah dalam rangka menciptakan keseimbangan antara kepentingan nasional yang sinergis dan tetap memperhatikan kondisi, kekhasan dan kearifan lokal dalam penyelenggaraan pemerintahan secara keseluruhan.

Adapun kewenangan Pemerintah pusat dalam menetapkan norma, standar, prosedur dan kriteria dilaksanakan oleh Kementerian dan Lembaga Pemerintah Non Kementerian. Hal tersebut sesuai ketentuan Pasal 16 ayat (3) yang berbunyi "kewenangan Pemerintah Pusat sebagaimana dimaksud pada ayat (1) dilaksanakan oleh kementerian dan lembaga pemerintah nonkementerian." 31 Ketentuan Pasal 16 tersebut menggambarkan suatu hubungan hukum antara Perda dengan Peraturan Menteri, sepanjang suatu Peraturan Menteri memuat norma, standar, prosedur dan kriteria terhadap pembentukan dan pelaksanaan kebijakan di daerah ada kewajiban hukum bagi pembentuk kebijakan daerah untuk patuh terhadap peraturan tersebut dengan catatan bahwa Peraturan Menteri harus terlebih dahulu dimuat ke dalam hierarki peraturan perundang-undangan sebagaimana tergambar dalam Undang-Undang Nomor 12 Tahun 2011 tentang Pembentukan Peraturan Perundang-undangan. Hal tersebut penting karena ketidak jelasan

\footnotetext{
${ }^{31}$ Lihat Pasal 16 Undang-Undang Nomor 23 Tahun 2014 tentang Pemerintahan Daerah.
}

\section{2 | Pasca Sarjana Magister Hukum Universitas Borneo Tarakan}


kedudukan Peraturan Menteri di dalam hierarki peraturan perundangundangan akan mengakibatkan sulitnya menakar tinggi rendahnya kedudukan dari Peraturan Menteri dimaksud, hal tersebut sejalan dengan teori yang dikemukakan oleh Hans Kelsen.

\section{PENUTUP}

\section{A. Kesimpulan}

Dari hasil pembahasan yang telah diuraikan, penulis berkesimpulan sebagai berikut:

1. Ratio Legis penempatan Peraturan Menteri dalam ketentuan Pasal 8 ayat (1), karena menurut pembentuk undang-undang Menteri berpotensi melakukan abuse of power (penyalahgunaan kewenangan) mengingat terdapat kebebasan Menteri untuk membentuk peraturan yang didasari oleh kewenangan yang juga berkualifikasi sebagai peraturan perundangundangan. Semestinya kewenangan tersebut dimaknai sebagai kewenangan penyelenggaraan pemerintahan (bestuur), karena Menteri tidak memiliki kewenangan atribusi untuk membentuk peraturan perundang-undangan dan Peraturan Menteri yang dibentuk berdasarkan kewenangan hanya berkualifikasi sebagai peraturan kebijakan (beleidsregel) sedangkan Peraturan Menteri yang dibentuk berdasarkan perintah peraturan perundang-undangan yang lebih tinggilah yang berkualifikasi sebagai peraturan perundang-undangan delegasian (delegated legislation).

2. Implikasi yuridis kedudukan Peraturan Menteri terhadap pembentukan Perda adalah tidak adanya kewajiban hukum bagi pembentuk Perda untuk menjadikan Peraturan Menteri sebagai acuan dalam pembentukan Perda, termasuk memuatnya ke dalam dasar hukum (mengingat) dalam konteks legal drafting pembentukan Perda. Hal ini karena terdapat asas hukum yang menyatakan bahwa peraturan yang tinggi mengeyampingkan peraturan yang lebih rendah (lex superior derogat legi

\section{Pasca Sarjana Magister Hukum Universitas Borneo Tarakan}


inferiori). Asas tersebut secara implisit dapat dimaknai pula bahwa sesungguhnya Pembentukan Perda hanya wajib tunduk dan patuh terhadap peraturan perundang-undangan yang ada di atasnya/lebih tinggi, sementara yang menjadi legal formal untuk mengukur tinggi atau rendahnya posisi dan kekuatan hukum dari peraturan perundangundangan adalah hierarki peraturan perundang-undangan.

\section{B. Saran}

Dari Pembahasan yang telah penulis simpilkan di atas, terdapat beberapa saran yang perlu penulis sampaikan diantaranya:

1. Undang-Undang Nomor 15 Tahun 2019 tentang Perubahan atas UndangUndang Nomor 12 Tahun 2011 tentang Pembentukan Peraturan Perundang-undangan pada kenyataannya belum mengakomodir perubahan terhadap ketentuan Pasal 7 dan Pasal 8 Undang-Undang dimaksud oleh karenanya dalam rangka penataan regulasi sebaiknya dilakukan revisi kembali terhadap Undang-Undang Nomor 12 Tahun 2011 tentang Pembentukan Peraturan Perudang-undangan khususnya pada Pasal 7 ayat (1) yang mengatur terkait hierarki peraturan perundang-undangan dengan memasukkan Peraturan Menteri yang terkategori sebagai peraturan perundang-undanagan delegasian (delegated legislation) kedalam hierarki peraturan perundang-undangan di bawah Peraturan Presiden, mengingat Menteri adalah pembantu Presiden, selanjutnya Peraturan Menteri yang terkategori sebagai Peraturan Kebijakan (beleidsregel), harus tetap diakui keberadaannya dalam Undang-Undang tentang Pembentukan Peraturan Perundangundangan, mengingat peraturan tersebut secara faktual masih dibutuhkan sepanjang memuat ketentuan teknis dalam rangka pengaturan hal-hal yang berkaitan dengan Norma, Standar, Kriteria, dan Prosedur (NSPK) urusan Pemeirntahan tertentu. Selain kebutuhan penempatan Peraturan Menteri kedalam hierarki peraturan perundangundangan, kebutuhan terkait pengaturan materi muatan Peraturan

\section{4 | Pasca Sarjana Magister Hukum Universitas Borneo Tarakan}


Menteri juga sangat mendesak untuk dilakukan untuk memastikan apakah Peraturan Menteri tersebut terkategori sebagai Peraturan Perundang-undangan atau sebagai Peraturan Kebijakan.

3. Berkaitan dengan Pembentukan Perda, bagi para Pembentuk Perda baik dari Pemerintah melalui Perangkat Daerah Pemrakarsa bersama dengan Bagian Hukum Kabupaten/Kota atau Biro Hukum Provinsi maupun dari Dewan Perwakilan Rakyat Daerah (DPRD) melalui Panitia Khusus (Pansus) Pembahas Rancangan Perda, sebaiknya tidak menjadikan Peraturan Menteri sebagai landasan yuridis dalam penyusunan Naskah. Akademik dan Draft Rancangan Perda yang akan disusun, selama Peraturan Menteri belum menjadi bagian dari hierarki peraturan perundang-undangan. Selain itu, tingginya dinamika perubahan dari Peraturan Menteri juga akan menyulitkan para pembentuk Perda untuk menyesuaikan terhadap perubahan Peraturan Menteri tersebut. Peraturan Menteri sepanjang memuat norma, standar, prosedur dan kriteria dalam rangka pelaksanaan urusan pemerintahan tertentu, seharusnya bersifat operasional dan langsung dapat dilaksanakan oleh Pemerintah Daerah, hal ini juga dapat mengurangi pembentukan produk hukum daerah yang hanya berisi dan bersifat teknis.

\section{DAFTAR PUSTAKA}

\section{Artikel pada Jurnal}

Huda, Ni'matul. Kedudukan Perda dalam hierarki Peraturan Perundangundangan. Hukum 13, No. 1 (2016): 27-37.

Wicaksana, Dian Agung. "Implikasi dan Re-Eksistensi Tap MPR dalam Hierarki Peraturan Perundang-undangan terhadap Jaminan atas Kepastian Hukum yang Adil di Indonesia”. Konstitusi 10, No. 1 (2013): 143-178.

\section{Buku}

Manan, Bagir. Teori dan Politk Konstitusi. Cetakan Kedua. Yogyakarta: FH UII 
Press, 2004.

Ranggawidjaja, Rosjldi. Pedoman Teknik Perancangan Peraturan Perundangundangan. Bandung: Cita Bhakti Akademika, 1996.

Farida, Maria. Ilmu Perundang-undangan, Jenis Fungsi dan Materi Muatan. Yogyakarta: Kanisius, 2007.

\section{Artikel pada Prosiding / Conference Paper}

Ahmad Zein, Yahya. "Problematika Hirarkhi Peraturan Peundang-undangan Indonesia (Studi Pasal 8 ayat (1) UU 12 tahun 2011 tentang Pembentukan Peraturan peraturan perundang-undangan". Konfrensi Nasional Hukum Tata Negara ke-4, Jember: 2017

\section{Peraturan Perundang-undangan}

Undang-Undang Nomor 39 Tahun 2008 tentang Kementerian Negara. (LNRI Nomor 166 Tahun 2008 - TLNRI Nomor 4916)

Undang-Undang Nomor 12 Tahun 2011 tentang Pembentukan Peraturan Perundang-Undangan. (LNRI Nomor 82 Tahun 2011 - TLNRI Nomor 5234)

Undang-Undang Nomor 23 Tahun 2014 tentang Pemerintahan Daerah. (LNRI Nomor 244 Tahun 2014 - TLNRI Nomor 5587)

Undang-Undang Nomor 2 Tahun 2015 tentang Penetapan Peraturan Pemerintah Pengganti Undang-Undang Nomor 2 Tahun 2014 tentang Perubahan Atas

Undang-Undang Nomor 23 Tahun 2014 tentang Pemerintahan Daerah Menjadi Undang-Undang. (LNRI Nomor 24 Tahun 2015 - TLNRI Nomor 5657)

Undang-Undang Nomor 9 Tahun 2015 tentang Perubahan Kedua Atas Undang-

Undang Nomor 23 Tahun 2014 tentang Pemerintahan Daerah. (LNRI Nomor 58 Tahun 2015 - TLNRI Nomor 5679)

Undang-Undang Nomor 15 Tahun 2019 tentang Perubahan Atas Undang-Undang Nomor 12 Tahun 2011 tentang Pembentukan Peraturan Perundangundangan. (LNRI Nomor 183 Tahun 2019 - TLNRI Nomor

136 | Pasca Sarjana Magister Hukum Universitas Borneo Tarakan 